\title{
The Effects of Growth, Size and Capital Structure Decisions on Profitability in Istanbul Stock Exchange (ISE):2008-2017
}

\author{
${ }^{1}$ Selahattin KOÇ*, ${ }^{2}$ Zekai ŞENOL \\ ${ }^{1}$ Associated Professors, Cumhuriyet University, Faculty of Economics and Administrative Sciences, \\ Department of Business Administration. \\ ${ }^{2}$ Assistant Professors, Cumhuriyet University, Faculty of Economics and Administrative Sciences, \\ Department of Banking and Finance.
}

\begin{abstract}
The effect of firm size, growth and capital structure on firm profit rates has been searched by economists for several decades. The aim of this paper is to investigate the impacts of size, liquidity, growth and capital structure decisions on profitability in Stock Exchange Istanbul (BIST). For this aim, annual data of 114 manufacturing industry companies which are active at the moment in BIST. The financial data set covers the period 2005-2017. Results of the study using panel data analysis shows that while the ratios with regarding capital structure decisions negatively affect profitability, whereas size liquidity and growth positively affects profitability.
\end{abstract}

Keywords: Growth, Capital Structure, Profitability, ISE, Panel Data Analysis.

JEL Classification: D21, G32, C33, L25

\section{Introduction}

The final theoretical justification relating firm size and profitability arise from the strategic groups concept developed by Caves and Porter (1977) and Porter (1979). Caves and Porter describe strategic groups as consisting of clusters of firms within each industry who confront similar operating conditions (Amato, 2007). The study of factors determining the profitability of companies has guaranteed special attention over time by various fields of scientific knowledge. Take into account in Industrial economics the competition existing in the markets where companies operate as fundamental in explaining company profitability (Porter, 1980; Slater \& Olson, 2002; Nunes at all.2009).

Goddard et al. (2005), have suggested, strategic management and accountancy and finance approaches, considers the size, market power, debt, and liquidity is the profitability determinants of companies. In this study, we searched if there is any effect on profitability such as firm size, market power, debt and liquidity in BİST.

The effect of firm size, growth and capital structure on firm profit rates have been searched by economists for several years. Some of this researchs says that there are positive relation between the dependent and independent variables, which are mentioned above. When is looked this studies, concerning the relation between firm size and profitability are reviewed by Alexander (1949), Stekler (1964), Hall and Weiss (1967), Marcus (1969), Shepherd (1972), Scherer (1973), Smyth et al. (1975), Fiegenbaum and Karnani (1991), Majumdar (1997), Ozgulbas et al. (2006), Jonsson (2007) Serrasqueiro and Nunes (2008), Lee (2009), Stierwald (2009), Karadeniz and Iskenderoğlu (2011), Saliha and Abdessatar (2011), Akbas and Karaduman (2012), Shubita and Alsawalhah (2012), Dogan (2013), Vijayakumar and Tamizhselvan (2010), Papadognas (2007), had found a positive relation between firm size and profitability. Schmalensee (1985) has reached that, profitability is not closely related to any feature of the firm, concluding instead that profits are more closely connected to the market in which the firm operates. He has stated that, industry effects dominate firm effects in explaining cross- sectional profit rate variation.

On the other hand, Becker et al. (2010), Banchuenvijit (2012), Amato and Burson (2007), have found a negative relation between firm size and profitability. Hovey (2007), according to the result of his work on 
selected companies on the Chinese Stock leverage has a significant negative relationship with profitability Moballeghi and Moghaddam (2013), has reached that, financial leverage has no relationship with profitability. Hovey's (2007) paper shows that leverage has a significant negative relationship with profitability, on stock exchanges in Chinese listed companies.

Methodologically, to estimate the relationship between the profitability of Stock Exchange Istanbul (BIST) and its determinants, we used panel data analysis. Adams and Buckle (2003) use static panel models to determine the relationship between profitability and it's determinants. Goddard et al. (2005), with the additional aim of testing the persistence of profitability, estimate the relationship between profitability and its determinants using the generalized method of moments (GMM) (1991) dynamic estimator. In this study, just as Nunes et al. (2009), we also aim to test persistence of BIST profitability. For this purpose, as well as using static panel models, we use various dynamic estimators, least squares dummy variable corrected (LSDVC) (2005) estimators, this last one being appropriate in situations, where the number of observations is not very high. By using various estimators, we want to check if there is a relationship with the profitability of the BIST industry service.

The aim of this paper is to investigate the effect of firm size, liquidity, leverage and growth on profitability. In this paper, data of 114 companies which were active in Stock Exchange Istanbul (BIST) between the years 2008-2017 has been used. "Return on Assets" (ROA) and "Return on Equity" (ROE) have been used as indicators of firm profitability and total assets, liquidity, leverage, total sales, and sales growth have been used as indeipendent variables.

This paper consists of five sections. The paper measuring the effect of firm size, liquidity, leverage and growth on profitability have been summarized, in the second section following the introduction. The third section consists of the introduction of dependent and independent variables and explanation of methodology and sampling of the paper. Forth section covers the results of the analysis. And a general assessment of the paper has been asserted in the last section.

\section{Persistence of profitability}

Profitability can be affected by internal factors or external factors. Internal factors are reflected by operational decisions and companies size, while external factors are reflected by the type of industry that the companies switch on it's business and the macro factors that might affect directly to the companies performance (Moballeghi and Moghaddam, 2013).

The continuity of company profitability is influenced by the competitive dynamics of the markets where they operate. Dilling-Hansen (2005) make a decisions that large companies have a major possibility, compared with small companies, of achieving higher persistence of profitability, given that their greater scale allows them to cope with possible alterations in market conditions more successfully. On the other hand Hawawini, Subramanian, and Verdin (2003) and Schumacher and Boland (2005) conclude that the persistence of profitability of companies depends on their own specific characteristics and those of the markets where they operate (Nunes et al, 2007).

Profitability is the ratio of net profit in the year running to equity in last year (Profitability $=$ EIt $/$ BEt -1 )

\section{Company size:}

The size of a company affects performance in many ways. Main features of a large firm are it's diverse capabilities, the abilities to exploit economies of scale and scope and the formalization of procedures. These characteristics, by making the implementation of operations more effective, allow larger firms to generate superior performance relative to smaller firms (Majumdar, 1997).

This theory try to explain why firms exist, what forms firm and market boundaries and why there are differences in their organisation and performance (Pervan and Visic, 2012). Winter (1994), Hardwick (1997), Wyn (1998) and Gschwandtner (2005) stated that company size is very important for rates of profitability. Large company size allows for taking greater advantage of economies of scale, a greater possibility of diversifying the product and production activities.

On the other hand Pi and Timme (1993) states that large company size can imply diminished profitability. The authors state that large company size can contribute to less control of the management's behaviour. Jensen and Murphy (1990) also reaches parallel result in their search, large company size means more job 
security for managers and higher salaries, and can lead to behaviour that deviates from the aim of improving the financial performance of companies (Nunes at all, 2007).

Writers such as Friend and Lang (1988), Gönenç and Arslan (2003), Deesomsak at all. (2004), Padron at all. (2005), Saliha and Abdessatar (2011), Doğan (2013) had used "Total Assets" as firm size indicator. Writers such as Rajan and Zingales (1995), Wiwattanakantang (1999), Çağlayan (2006), Huang and Song (2006), Serrasqueiro and Nunes (2008), Akbaş and Karaduman (2012), Shubita and Alsawalhah (2012) had used "Total Sales" as firm size indicator. Bilkey and Tesar (1977), Cavusgil and Naor (1992), Holzmuller and Kasper (1991), Bonaccorsi (1992), Archarungroj and Hoshino (1998), Jonsson (2007), Serrasqueiro and Nunes (2008), Banchuenvijit (2012) had measured firm size, using number of employees.

\section{Growth}

Growth has been a focus in the literature with many researchers combining growth with entrepreneurship (Davidsson et al, 2002). Growth as a measure of firm performance has had mixed results in the literature (Fitzsimmons at all, 2005). The use of growth as a measure of firm performance is generally based on the belief that growth is a vanguard to the access to sustainable competitive advantages and profitability (Markman and Gartner, 2002). Most of the writers had used the growth is there any effect on profitability or vice-versa. Some writers have put forward that, increased company growth can mean diminished profitability such as Greiner (1972). Serrasqueiro(2009), he had used dynamic panel estimators, we test empirically the relationship between the growth of Portuguese companies and their profitability. The empirical evidence obtained indicates that growth in Portuguese companies means increased profitability. Sexton et al (2000) put forward that between firm profitability and sustainable growth was correlated.

According to Davidsson (1989), Delmar, Davidsson, and Gartner (2003) and Wiklund, Davidson, and Delmar (2003), the relationship between company growth and profitability can be positive or negative. On the other hand, increased growth can contribute to a breakdown of informal relationships established over time in companies, greater growth requiring greater formality in relationships at work, which in the shortterm can be difficult to achieve efficiently, this leading to diminished company profitability. However greater growth can result in greater profitability, as a result of increased motivation among employees who expect greater gains in the future, gains resulting from greater company size (Serrasqueiro, 2009).

\section{Debt}

In recent years, a few theories have been proposed to explain the variation in debt ratios across firms. The theories suggest that firms select capital structures depending on attributes that determine the various costs and benefits associated with debt and equity financing (Titman and Vessels, 1988). Role of debt in firms' performance is one of the main objectives of contemporary researches such as Goddard et al. (2005), Berger and Bonaccorsi (2006), Rao et al. (2007), Baum et al. (2007), Weill (2008), Nunes et al. (2009), Margaritis and Psillaki (2010) and Kebewar (2012).

Some authers like Majumdar and Chhibber (1999), Eriotis et al. (2002), Goddard et al. (2005), Rao et al. (2007), Zeitun and Tian (2007) and Nunes et al. (2009) have found negative effect between debt and profitability. However, Baum et al. (2006) and (2007), Berger and Bonaccorsi (2006), Margaritis and Psillaki (2007) and (2010), have found positive effect between debt and profitability. Besides, Simerly and Li (2000), Mesquita and Lara (2003) and Weill (2008), have found both effects in their papers. In addition, Berger and Bonaccorsi (2006), Margaritis and Psillaki (2007) and Kebewar and Shah (2012) have found the presence of a non- linear effect.

\section{Liquidity}

Liquidity is a very important instrumental factor for business. A broad literature exists surrounding the analysis of liquidity holdings for firms. The economics and finance literature analyze four possible reasons for firms to hold liquid assets; the transaction reason (Miller and Orr 1966), the precautionary reason (Opler at all. 1999), the tax reason (Foley at all. 2007) and finally the agency reason (Jensen 1986). An overview of the rationale behind those reasons can be found in Bates, Kahle and Stulz (2008).

Overall, the evidences has suggested that the adaptation of liquidity strategies does not have a significant impact on profitability. Only increased use of liquidity forecasting and short-term financing during the financial crises have a positive impact on profitability. Furthermore, it has found that the importance of key ratios, which monitors companies' liquidity have not changed between the studied time points. Monitoring 
and forecasting on liquidity levels and making more short-term investments can provide gains in profitability. Based on the findings, the adjustment of liquidity practices is beneficial for the companies, even though benefits are not always directly measurable as profitability (Lamberg and Valming, 2009).

Boose (1993), Adams (1996), Pottier (1998) and Adams and Buckle (2003) has put forward that greater level of company liquidity can mean diminished profitability, given the possibility of managers investing in projects that allow them to increase their prestige making the company grow beyond the optimal level. On the other hand Goddard et al. (2005) has found in their paper, companies with higher levels of liquidity tends to be more profitable.

\section{Asset structure}

Griliches and Lichtenberg (1984) and Nucci et all. (2005) have concluded that, companies with greater levels of intangible assets are more inclined to innovation, with more specific projects for the improvement of human capital, greater expense on investigation and development and a greater number of patents, could contribute to a negative relationship between the percentage of tangible assets and financial performance. Deloof (2003) also has put forward that, companies which have higher levels of tangible assets are tend to be less profitable.

\section{Literature review}

Next, we present the possible relationships between explanatory variables and the profitability of the BISST.

Amoto and Burson (2007), searched empirically test the relationship between firm size and profitability for the financial services sector using a data set that covers a broad range of firm sizes in their study. They reached two important results. First, there is evidence of a cubic relationship between return on assets and firm size. Moreover, the cubic function displays a positive, negative, positive sign pattern that indicates greater profit opportunities for small and large firms as compared to medium- sized companies. Their search result is consistent with Porter's (1985 and 1998) stuck in the middle hypothesis that suggests that there are profit opportunities for both small and large firms. The second major finding relates to the importance of industry effects in explaining cross- sectional variation in financial services profit rates. Industry effects explain approximately ten percent of the total variation in the profit rate. Michael Porter, suggest that the relationship between firm size and profitability may be non-linear.

Özgülbaş et al. (2006) have searched the effect of firm size on performance over the firms operating in Istanbul Stock Exchange between the years 2000 and 2005. They had found that, big scale firms have higher performance as a result of their study. Similarly, Jonsson (2007) also had studied the relation between profitability and size of the firms operating in Iceland. The finding of his paper has shown that big firms have a higher profitability compared to small firms.

Serrasqueiro and Nunes (2008) had searched the relation between the size and performance of big and small scale firms operating in Portugal. They had found positive and statistically significant relations between the size and performance of the firms as a result of the study using the data belonging to the years 1999-2003. Likewise, Lee (2009) also had found a positive relationship between the size and the profitability of the firms operating in the USA between the years 1987-2006.

Majundar (1997), in his paper briefly, reports the results of an empirical study investigating the impacts that size and age have on the economic performance of firms in the Indian industry. He had used contemporary data for an extensive sample of 1020 Indian firms. In India, older firms are found to be more productive and less profitable, whereas the larger firms are, conversely, found to be more profitable and less productive.

Pervan and Visic (2012), searched firm size and evaluated its influence on firm profitability. They put forward that firm performance is affected by a variety of internal and external variables. Their analysis was conducted for the 2002-2010 period in Croatia and the results revealed that firm size has a significant positive (although weak) influence on firm profitability. Additionally, assets turnover and debt ratio also showed statistically significantly influence firms' performance while the current ratio didn't prove to be an important explanatory variable of firms' profitability.

Doğan (2013), investigated the effect of firm size on profitability. In his study, data of 200 companies which were active in Istanbul Stock Exchange (ISE) between the years 2008 and 2011. "Return on Assets" (ROA) had used as indicators of firm profitability and total assets, total sales and number of employees had been 
used as indicators of size. Multiple regression and correlation methods had been used in empirical analyses. The result of the analysis indicates a positive relation between size indicators and profitability of firms. Control variables as the age of the firms and leverage rate have been found in a negative relation with ROA, but liquidity rate and ROA have been determined to have a positive relation.

\section{Database and variables}

\section{Database}

The data source used in this paper is the published database of Public Disclosure Platform (KAP). Balance Sheets and Income Statements of 114 manufacturing industry firms, which are present in Stock Exchange Istanbul (BIST). The period of study covers the years between 2000 and 2012

\section{Variables}

A summary of the variables and suitable measurements is given in Table 1. The dependent variable is profitability, given by the ratio of operational results to assets and equity. As independent variables we consider: (1) size, given by the assets logarithm; (2) growth, given by the rate of sales and assets growth; (3) debt, given by the ratio of total liabilities to assets; (4) liquidity, given by the ratio of current assets to shortterm liabilities.

\section{Table 1: Summary Statistics}

\begin{tabular}{|l|r|r|r|r|r|}
\hline \multicolumn{1}{|l|}{ Variables } & \multicolumn{1}{l|}{ Mean } & \multicolumn{1}{l|}{ Std. Dev. } & \multicolumn{1}{l|}{ Maximum } & \multicolumn{1}{l|}{ Minimum } \\
\hline ROA & 1,482 & 5.381113 & 10.23082 & -51.67 & 92.8 \\
\hline ROE & 1,482 & 6.721727 & 31.25872 & -431.94 & 617.79 \\
\hline LIQ & 1,482 & 2.346559 & 2.106235 & 0.10 & 24.98 \\
\hline LEV & 1,482 & 0.434831 & 0.214816 & 0.03 & 1.00 \\
\hline SIZE & 1,482 & $1.24 \mathrm{e}+09$ & $3.15 \mathrm{e}+09$ & $1.19 \mathrm{e}+07$ & $3.82 \mathrm{e}+10$ \\
\hline SGROWTH & 1,482 & 13.27917 & 31.42779 & -83.46 & 647.14 \\
\hline AGROWTH & 1,482 & 0.138427 & 0.256207 & -0.51 & 4.26 \\
\hline
\end{tabular}

\section{Source: Created by Authors}

Asset profitability and equity profitability ratios of the sample firms are 5,38\% and 6,72\% respectively. The fact that the difference between the two profitability ratios is low means that the use of liabilities does not increase the return on equity. The average liquidity ratio of firms is $2,34 \%$. Accordingly, it can be said that firms have sufficient liquidity and have the power to pay short-term liabilities. The average leverage ratio of companies is $0,43 \%$. It can be said that this ratio is below the general leverage ratio $(0,50 \%)$ and it is sufficient to pay the liabilities of the companies. On average, the sum of the assets of the sample firms is 1.24 Billion Turkish Lira. According to the summary statistics, firms increased their sales by $13 \%$ and their assets by $0.13 \%$ in the period of 2005-2017.

\section{Table 2: Measurement of variables}

\begin{tabular}{|l|l|}
\hline Variables & Measurement \\
\hline Dependent variables & \\
\hline Profitability (ROA) and (ROE) & Ratio between operational results and total assets \\
\hline Independent variables & \\
\hline Size (SIZE) & Logarithm of assets \\
\hline Growth (SGROWTH) and (AGROWTH) & Growth of sales and assets \\
\hline Leverage (LEV) & Ratio between total liabilities and total assets \\
\hline Liquidity (LIQ) & Ratio between current assets and short-term debt \\
\hline
\end{tabular}


The correlation matrix is shown in Table 3. Accordingly, while the rate of return on assets (ROA) is positively correlated with liquidity (LIQ), sales growth (SGROWTH) and assets growth (AGROWTH) rates, it is negatively correlated with leverage ratio (LEV). Likewise, the return on equity ratio (ROE) is positive with liquidity (LIQ), sales growth (SGROWTH) and assets growth (AGROWTH) rates, whereas it is negatively correlated with leverage ratio (LEV). There is no correlation between the variables that negatively affects the establishment of the model.

\section{Table 3: Correlations}

\begin{tabular}{|l|l|l|l|l|l|l|l|}
\hline Variables & ROA & ROE & LIQ & LEV & SIZE & SGRW & AGRW \\
\hline ROA & 1 & & & & & & \\
\hline ROE & $\begin{array}{l}0,643 \\
(0,000)\end{array}$ & 1 & & & & & \\
\hline LIQ & $\begin{array}{l}0,403 \\
(0,000)\end{array}$ & $\begin{array}{l}0,138 \\
(0,000)\end{array}$ & 1 & & & & \\
\hline LEV & $-0,459$ & $\begin{array}{l}-0,249 \\
(0,000)\end{array}$ & $\begin{array}{l}-0,657 \\
(0,000)\end{array}$ & 1 & & & \\
\hline SIZE & $\begin{array}{l}0,000) \\
(0,229)\end{array}$ & $\begin{array}{l}0,040 \\
(0,141)\end{array}$ & $\begin{array}{l}-0,089 \\
(0,001)\end{array}$ & $\begin{array}{l}0,081 \\
(0,003)\end{array}$ & 1 & & \\
\hline SGROWTH & $\begin{array}{l}0,262 \\
(0,000)\end{array}$ & $\begin{array}{l}0,175 \\
(0,000)\end{array}$ & $\begin{array}{l}-0,036 \\
(0,164)\end{array}$ & $\begin{array}{l}0,037 \\
(0,151)\end{array}$ & $\begin{array}{l}0,036 \\
(0,185)\end{array}$ & 1 & \\
0 & $\begin{array}{l}0,154 \\
(0,000)\end{array}$ & $\begin{array}{l}0,134 \\
(0,000)\end{array}$ & $\begin{array}{l}-0,052 \\
(0,044)\end{array}$ & $\begin{array}{l}0,131 \\
(0,000)\end{array}$ & $\begin{array}{l}0,033 \\
(0,227)\end{array}$ & $\begin{array}{l}0,255 \\
(0,000)\end{array}$ & 1 \\
\hline AGROWTH & \multicolumn{7}{l|}{} \\
\hline
\end{tabular}

\section{Source: Created by Authors}

\section{Methodology}

The study applied to the 114 manufacturing industry firms listed at the Stock Exchange Istanbul (BIST) from the period of 2005 to 2017. Currently, there are 179 manufacturing industry companies registered in BIST. During the sampling period, 114 companies were identified, which continue to operate and their data can be accessed. For this purpose, we have developed the following hypotheses.

\section{Research Hypotheses}

The following three hypotheses are made for this research:

First hypothesis: There is a significant relationship between firm size and profitability of companies in various industries listed at ISE.

Second hypothesis: There is a significant relationship between growth and profitability of companies in various industries listed at the ISE.

Third hypothesis: There is a significant relationship between financial leverage and profitability of companies in various industries listed at the ISE.

\section{Panel models}

$$
\begin{aligned}
& \text { ROA }_{\text {it }}=\beta_{0 \mathrm{it}}+\beta_{1 \mathrm{it}} \mathrm{LIQ}_{1 \mathrm{it}}+\beta_{2 \mathrm{it}} \mathrm{LEV}_{2 \mathrm{it}}+\beta_{3 \mathrm{it}} \text { LNSIZE }_{3 \mathrm{it}}+\beta_{4 \mathrm{it}} \mathrm{SGROWTH}_{4 \mathrm{it}}+ \\
& \beta_{5 \mathrm{it}} \mathrm{AGROWTH}_{5 \mathrm{it}}+\mathrm{u}_{\mathrm{it}} \\
& \mathrm{ROE}_{\mathrm{it}}=\beta_{0 \mathrm{it}}+\beta_{1 \mathrm{it}} \mathrm{LIQ}_{1 \mathrm{it}}+\beta_{2 \mathrm{it}} \mathrm{LEV}_{2 \mathrm{it}}+\beta_{3 \mathrm{it}} \mathrm{LNSIZE}_{3 \mathrm{it}}+\beta_{4 \mathrm{it}} \mathrm{SGROWTH}_{4 \mathrm{it}}+ \\
& \beta_{5 \mathrm{it}} \mathrm{AGROWTH}_{5 \mathrm{it}}+\mathrm{u}_{\mathrm{it}}
\end{aligned}
$$

Where, $\mathrm{i}$ represents each of the companies; $\mathrm{t}$ represents the period of time; $\mathrm{ROE}_{\mathrm{i}, \mathrm{t}}$ and $\mathrm{ROE}_{\mathrm{i}, \mathrm{t}}$ are the profitability; $\mathrm{SIZE}_{\mathrm{i}, \mathrm{t}}$ is the size; GROWTH $\mathrm{G}_{\mathrm{i}, \mathrm{t}}$ is the growth; $\mathrm{LEV}_{\mathrm{i}, \mathrm{t}}$ is the debt; $\mathrm{LIQ}_{\mathrm{i}, \mathrm{t}}$ is the liquidity and $u_{i, t}=v_{i}$ $+e_{i, t}$, with $\mathrm{v}_{\mathrm{i}}$ being the non-observable individual effects of companies and $\mathrm{e}_{\mathrm{i}, \mathrm{t}}$ the error which is assumed to have a normal distribution (Nunes, 2009).

Panel data analysis was conducted to investigate the internal determinants of firm profitability. Panel data is more widespread in econometric studies according to time series and cross-section data. The reason for this 
is that more data can be obtained in the panel data set. Panel data consists of time and units. Therefore, a stationary condition is required for panel data. Panel unit root tests are divided into two types: panel unit roots tests assuming cross-sectional independence and panel unit roots tests assuming for cross-sectional dependence. In other words, unit root tests are divided into first-generation and second generation unit root tests. Which unit root tests will be used is determined by cross-sectional dependency tests.

Table 4: Cross-Section Dependence Tests

\begin{tabular}{|l|l|l|l|l|}
\hline Variables & $\begin{array}{l}\text { Breusch- } \\
\text { Pagan LM }\end{array}$ & $\begin{array}{l}\text { Pesaran scaled } \\
\text { LM }\end{array}$ & $\begin{array}{l}\text { Bias- } \\
\text { Corrected } \\
\text { scaled LM }\end{array}$ & Pesaran CD \\
\hline ROA & 9984.179 & 31.21774 & $\begin{array}{l}26.46774 \\
(0,0000)\end{array}$ & $\begin{array}{l}23.57792 \\
(0,0000)\end{array}$ \\
\hline ROE & $(0,0000)$ & $(0,0000)$ & 20.85617 & 25.73271 \\
& 9347.272 & 25.60617 & $(0,0000)$ & $(0,0000)$ \\
\hline LIQ & $(0,0000)$ & $(0,0000)$ & 73.04644 & 15.60542 \\
& 15270.81 & 77.79644 & $(0,0000)$ & $(0,0000)$ \\
\hline LEV & $(0,0000)$ & $(0,0000)$ & 128.4437 & 43.69170 \\
& 21558.34 & 133.1937 & $(0,0000)$ & $(0,0000)$ \\
\hline LNSIZE & $(0,0000)$ & $(0,0000)$ & 463.3258 & 229.3934 \\
& 59567.09 & 468.0758 & $(0,0000)$ & $(0,0000)$ \\
\hline SGROWTH & $(0,0000)$ & $(0,0000)$ & 43.26770 & 60.85576 \\
& 11890.96 & 48.01770 & $(0,0000)$ & $(0,0000)$ \\
\hline AGROWTH & $(0,0000)$ & $(0,0000)$ & 10.11454 & 25.48113 \\
& 8128.109 & 14.86454 & $(0,0000)$ & $(0,0000)$ \\
\hline Note: Values in brackets indicate probabilities. & $(0,0000)$ & \\
\hline
\end{tabular}

\section{Source: Created by Authors}

As seen in the table, all of the variables have cross-sectional dependence. For this reason, the second generation unit root tests that Peseran CADF and PANICCA were used in the study to investigate the stationary of the variables.

Pesaran (2004) suggests a test in presence cross-section dependence that is applicable to a variety of panel models with short $\mathrm{T}$ and large $\mathrm{N}$ (Baltagi, 2014: 287). The cross-section average (CA) augmentation approach of Pesaran (2007) and Pesaran et al. (2013) and the principal components-based panel data analysis of non-stationarity in idiosyncratic and common components (PANIC) of Bai and Ng (2004, 2010) are among popular second-generation approaches for cross-section correlated panels. It is to Panicca, a combined approach that exploits the strengths of both CA and PANIC (Reese and Westerlund, 2015: 1)

Table 5: Pesaran's CADF Unit Root Test

\begin{tabular}{|l|l|l|l|l|l|l|l|}
\hline Variables & ROA & ROE & LIQ & LEV & LNSIZE & SGRW & AGRW \\
\hline Level & -2.608 & -2.660 & -2.383 & -1.793 & -1.952 & -3.225 & -2.990 \\
& $(0,000)$ & $(0,000)$ & $(0,000)$ & $(0,209)$ & $(0,009)$ & $(0,000)$ & $(0,000)$ \\
\hline Criticial & $\% 1$ & -2.160 & & & \\
Values & $\% 5$ & -2.040 & & & \\
\multicolumn{7}{|l|}{-1.980} \\
& $\% 10$ & -10 & & & \\
\hline
\end{tabular}

\section{Source: Created by Authors}

In Pesaran's CADF test, except for leverage (LEV), all variables are stationary at the level. On the other hand, the Panicca test shows that the leverage (LEV) variable is stationary. According to other unit root tests, the leverage (LEV) variable was considered to be stationary due to the strengthening of the PANICCA test for both CA and PANIC. 
Tablo 6: PANICCA Unit Root Test

\begin{tabular}{|l|l|l|l|l|}
\hline Level & ADF Test & $\mathbf{P}_{\mathbf{a}}$ & $\mathbf{P}_{\mathbf{b}}$ & PMSB \\
\hline ROA & -3.23109 & -10.173 & -5.26 & -3.158 \\
& $(0,0022)$ & $(0,0000)$ & $(0,0000)$ & $(0,0008)$ \\
\hline LEV & -3.25198 & -4.334 & -2.611 & -1.781 \\
& $(0,0012)$ & $(0,0000)$ & $(0,0045)$ & $(0,0375)$ \\
\hline LNSIZE & -3.60135 & -1.763 & -1.34 & -2.012 \\
& $(0,0012)$ & $(0,0389)$ & $(0,0900)$ & $(0,0221)$ \\
\hline SGROWTH & 1.12118 & -6.492 & -4.693 & -2.215 \\
& $(0,9405)$ & $(0,0000)$ & $(0,0000)$ & $(0,0134)$ \\
\hline Note: The values in brackets are the probability values. & -1.67 & -1.079 \\
& -3.22572 & $(0,0475)$ & $(0,1402)$ \\
\hline
\end{tabular}

\section{Source: Created by Authors}

\section{Findings}

Likelihood rates (LR) test is used to determine individual and time effects. As seen in Table 7, the null hypothesis was rejected, the unit and time effects were observed. Hausman test can bu used the contrast between Random Effect (RE) and Fixed Effect (FE) estimators. The null hypothesis is valid in the ROA model. Accordingly, the RE estimator has been used. On the other hand, the null hypothesis was rejected in the ROE model. Therefore, the FE estimator has been used.

Leven, Brown and Forsythe's test was used for the heteroskedasticity in the RE model, whereas modified Wald was used in the FE model. In both tests, the null hypothesis is valid. Therefore, there is heteroskedasticity in the models. For the autocorrelation and cross-sectional dependence tests, DurbinWatson and Pesaran CD tests were used respectively. In panel data analysis, robust standard errors should be used with heteroskedasticity, autocorrelation and cross-section dependency. In this study, Arellano, Froot and Rogers estimator and Driscoll Kraay standard errors were used, according to the results of hypothesis tests.

Table 7: Empirical Results (The Effect of Growth, Size, Liquidity and Leverage on Profitability)

\begin{tabular}{|c|c|c|c|c|c|c|}
\hline & \multirow{2}{*}{\multicolumn{3}{|c|}{$\begin{array}{l}\text { Random-effects GLS Regression } \\
\text { (Arellano, Froot ve Rogers Estimator) } \\
\text { ROA }\end{array}$}} & \multicolumn{3}{|c|}{$\begin{array}{l}\text { Fixed-effects Regression with Driscoll- } \\
\text { Kraay Standard Errors }\end{array}$} \\
\hline & & & & & & \\
\hline & Coef & $\begin{array}{l}\text { Robust Std. } \\
\text { Err. }\end{array}$ & Z Stat & Coef & $\begin{array}{l}\text { Drisc/Kraay } \\
\text { Std. Err. }\end{array}$ & Z Stat \\
\hline Constant & -30.68329 & 7.604812 & $-4.03^{* * *}$ & -167.0206 & 33.62747 & $-4.97^{* * * *}$ \\
\hline LIQ & 0.7889072 & 0.299056 & $2.64^{* * * *}$ & $\begin{array}{l}- \\
0.4758839\end{array}$ & 0.5660443 & -0.84 \\
\hline LEV & -22.90633 & 2.818039 & $-8.13^{* * *}$ & -65.60124 & 22.60229 & $-2.90^{* * * *}$ \\
\hline LNSIZE & 2.151534 & 0.4197221 & $5.13^{* * * *}$ & 10.14395 & 1.997194 & $5.08^{* * * * *}$ \\
\hline SGROWTH & 0.0800293 & 0.019689 & $4.06^{\text {***\% }}$ & 0.148005 & 0.0327106 & $4.52^{* * * *}$ \\
\hline AGROWTH & 5.114406 & 1.371276 & $3.73^{* * * *}$ & 10.83671 & 1.931657 & $5.61^{\text {**** }}$ \\
\hline $\begin{array}{l}\text { LR Test (Chi2) } \\
\text { Cross-section } \\
\text { Period } \\
\text { Cross- } \\
\text { Section/Period }\end{array}$ & $\begin{array}{l}515.820^{* * *} \\
21.805^{* * *} \\
565.443^{* * *}\end{array}$ & & & $\begin{array}{l}137.859^{* * *} \\
9.749^{* * *} \\
152.032^{* * *}\end{array}$ & & \\
\hline $\begin{array}{l}\text { Hausman Test } \\
\text { (Prob>chi2) }\end{array}$ & 0.6794 & & & $16.55^{* * *}$ & & \\
\hline $\begin{array}{l}\text { Levene, Brown } \\
\text { and Forsythe's } \\
\text { Test }\end{array}$ & $\begin{array}{lr}\mathrm{W}_{0} & 4.097 \\
\mathrm{~W}_{50} & 3.1524 \\
\mathrm{~W}_{10} & 3.8251 \\
\end{array}$ & & & - & & \\
\hline
\end{tabular}




\begin{tabular}{|l|l|l|}
\hline $\begin{array}{l}\text { Modified Wald } \\
\text { (chi2) }\end{array}$ & - & $2.7 \mathrm{e}+05^{* * *}$ \\
\hline Durbin-Watson & 1.5352951 & 1.3623587 \\
\hline Pesaran CD & $17.200^{* * * *}$ & $12.889^{* * * *}$ \\
\hline Observations & 1.482 & 1.482 \\
\hline $\mathrm{R}^{2}$ & 0.3651 & 0.1100 \\
\hline Prob>F & 0.0000 & 0.0000 \\
\hline Note: ${ }^{* * *}$ and ${ }^{* * * *}$ denote significance at 10\%,5\% and 1\% levels, respectively \\
\hline
\end{tabular}

\section{Source: Created by Authors}

The results of the study are shown in the Table 7. While liquidity (LIQ), size (LNSIZE) and growth (SGROWTH and AGROWTH) affected return on assets (ROA) positively, leverage (LEV) was negatively affected. While size (LNSIZE) and growth (SGROWTH and AGROWTH) affected the return on equity (ROE) positively, leverage (LEV) affected negatively. The results of the two models are very similar. The only difference between the results of the two models is that the effect of liquidity (LIQ) on return on equity (ROE) is statistically insignificant.

The effect of liquidity on profitability was positive. Accordingly, it can be said that the firms use liquid assets effectively, they do not have excessive and insufficient liquidity and they have liquid assets that can pay short term liabilities. Firm size can affect profitability positively or negatively. The effect of firm size was positive in the study. Accordingly, it can be said that as firms grow, profitability will increase. As expected, the effect of growth on profitability was positive. The effect of leverage on profitability may be negative or positive. If financial leverage is positive, leverage increases profitability. Otherwise, leverage reduces profitability. In the study, the effect of leverage was negative. According to this, it can be said that financial leverage is negative, firms fail in debt management and the return on borrowing is lower than the borrowing cost.

The results of this study reveal similarities with some studies in the literature. As in this study, in the literature studies that Ozgulbas et al. (2006), Amoto and Burson (2007), Jonsson (2007), Serrasqueiro and Nunes (2008), Lee (2009), Pervan and Visic (2012) and Dogan (2013), the size of the company has been seen to increase profitability. Similarly to this study, it was found that leverage reduced profitability in some studies that they are Majumdar and Chhibber (1999), Eriotis et al. (2002), Goddard et al. (2005), Rao et al. (2007), Zeitun and Tian (2007) and Nunes et al. (2009).

\section{Results}

One of the most important objectives of businesses is profitability. Many factors including internal and external factors affect profitability in business. Internal factors are the factors that may change depending on the decisions of business management such as financial, managerial, marketing, product development and effective use of human resources. External factors may be in the form of macroeconomic factors such as exchange rate, interest rates, inflation, and current balance as well as institutional factors such as education level, rule of law, democracy, the functioning of bureaucracy, corruption.

In this study, internal factors affecting profitability were investigated in the 2005-2017 period and 114 firms. In the study, performed in the panel data analysis, it is seen that liquidity, size, and growth positively affect profitability, whereas the leverage has a negative effect on profitability. These results are important for business executives, investors and other business stakeholders.

According to the hypotheses which we developed,

It can be searched in the future,

\section{References}

[1.] Adams, M. (1996), "Investment Earnings and the Characteristics of Life Insurance Firms: New Zealand Evidence", Australian Journal of Management, 21(1), 41-55.

[2.] Adams, M., \& Buckle, M. (2003), "The Determinants of Corporate Financial Performance in the Bermuda Insurance Market”, Applied Financial Economics, 13(2), 133-143. 
[3.] Akbas, H. E., and Karaduman, H. A. (2012), "The Effect of Firm Size on Profitability: An Empirical Investigation on Turkish Manufacturing Companies" European Journal of Economics, Finance and Administrative Sciences, 55 , 21-27.s

[4.] Alexander, S.S., (1949), "The effects of size of manufacturing corporation on the distribution of rate of return", Review of Economics and Statistics, August, 229-235.

[5.] Amato, L. H. and Burson, T. E. (2007), "The Effect of Firm Size on Profit Rates in The Finacial Services", Journal of Economics and Economic Education Research, 8, 67-80.

[6.] Amato, L. H. and Burson, T. E. (2007), "The Effects of Firm Size on Profit Rates in the Financial Services", Journal of Economics and Economic Education Research, 8, Issue 1, 67 - 81.

[7.] Archarungroj, P. and Hoshino, Y. (1998), "The Impact of Firm Size on Export Performance and Attitudes: An Empirical Study on Thailand Exporters", Japanese Journal of Administrative Science, 12(2), 79 - 88.

[8.] Banchuenvijit, W. (2012), "Determinants of Firm Performance of Vietnam Listed Companies", Academic and Business Research Instıtute. http://aabri.com/SA12Manuscripts/SA12078.pdf (20 January 2014).

[9.] Baum, C. F., Schafer D. and Talavera, O. (2006), "The Effects of Short-Term Liabilities on Profitability: A Comparison of German and US Firms", Boston College Working Papers in Economics, 636, Boston College Department of Economics.

[10.] Baum, C. F.; Schafer, D. and Talavera, O. (2007), "The Effects of Short-Term Liabilities on Profitability: The Case of Germany", Money Macro and Finance (MMF) Research Group Conference 2006, 61, Money Macro and Finance Research Group.

[11.] Berger A. and Bonaccorsi di Patti, E. (2006), "Capital Structure and Firm Performance: A New Approach to Testing Agency Theory and An Application to the Banking Industry", Journal of Banking \& Finance, 30, 1065- 1102.

[12.] Bilkey, W.J. and George, T. (1977), "The Export Behavior of Smaller-Sized Wisconsin Manufacturing Firms", Journal of International Business Studies, 8 (1), 93-98.

[13.] Bonaccorsi, A. (1992), "On the Relationship between Firm Size and Export Intensity", Journal of International Business Studies, 23(4), 605-636.

[14.] Boose, M. (1993), "Investment Returns of Life Insurers: Tests of Agency Theory and Its Alternatives", Managerial Finance, 19 (8), 18-34.

[15.] Çağlayan, E. (2006), "Sermaye Yapısı Bileşenleri: Kantil Regresyon Modeli”, İktisat Işsletme ve Finans, 21 (248), 66-76.

[16.] Cavusgil, S. T. and Jacob, N. (1987), "Firm And Management Characteristics As Discriminators For Export Behavior", Journal of Business Research, 15 (3), 221-35.

[17.] Davidsson, P., Kirchoff, B., Hatemi-J, A, Gustavsson, H. (2002), "Empirical Analysis of Business Growth Factors Using Swedish Data", Journal of Small Business Management 40 (4), 332-349.

[18.] Deloof, M. (2003), "Does Working Capital Management Affect Profitability of Belgian Firms", Journal of Business Finance and Accounting, 30 (3-4), 573-588.

[19.] Deesomsak, R., Paudyal, K. \& Pescetto, G. (2004), "The Determinants of Capital Structure: Evidence From The Asia Pacific Region”, Journal of Multinational Financial Management, 14, 387-405.

[20.] Dilling-Hansen, M. (2005). "Small Firms Performance and Ownership Structure (Working Paper of the School of Economics and Management). Denmark: University of Aarhus.

[21.] Doğan, M. (2013), "Does Firm Size Affect The Firm Profitability? Evidence From Turkey", Research Journal of Finance and Accounting, 4, 53-60.

[22.] Eriotis, N. P.; Franguoli, Z. and Neokosmides, Z. V. (2002), "Profit Margin and Capital Structure: An Empirical Relationship", The Journal of Applied Business Research, 18, 85-89.

[23.] Fiegenbaum, A. \& Karnani, A. (1991), "Output Flexibility - A Competitive Advantage for Small Firms", Strategic Management Journal, 12, 101-114.

[24.] Fitzsimmons, J.R., Steffens, P. R., and Douglas E. J. (2005). "Growth and Profitability in Small and Medium Sized Australian Firms", AGSE Entrepreneurship Exchange, Melbourne

[25.] Foley, F., Hartzell, J., Titman, S., and Twite, G. (2007), "Why do Firms Hold so Much Cash? A Taxbased Explanation" Journal of Financial Economics, 86, 579-607. 
[26.] Friend, I. \& Lang, L.H.P. (1988), “An Emprical Test of the Impact of Managerial Self-Interest on Corporate Capital Structure", The Journal of Finance, 43 (2), 271-281.

[27.] Goddard, J., Tavakoli, M., \& Wilson, J. (2005), Determinants of Profitability in European Manufacturing and Services: Evidence From a Dynamic Panel Data. Applied Financial Economics, 15 (18), 1269-1282.

[28.] Gönenç, H. \& Arslan, Ö. (2003), "Uluslararası ve Yurtiçi Türk Reel Sektör Firmalarının Sermaye Yapıs1", IMKB Dergisi, 7, 41-63.

[29.] Greiner, L. (1972), "Evolutions and Revolutions as Organizations Grow", Harvard Business Review, 50(4), 37-46.

[30.] Griliches, Z., \& Lichtenberg, F. (1984), "R\&D and Productivity Growth at the Industry Level: Is There Still a Relationship? In", Z. Griliches (Ed.), R\&D, Chicago, IL: University of Chicago Press, Patents and Productivity (465-501).

[31.] Gschwandtner, A. (2005), "Profit Persistence in the 'Very' Long Run: Evidence From Survivors and Exiters", Applied Economics, 37 (7), 793-806.

[32.] Hall. M \& Weiss, L. (1967), "Firm Size and Profitability", The Review of Economics and Statistics, 49 (3), $319-331$.

[33.] Hardwick, P. (1997), "Measuring Cost Inefficiency in the UK Life Insurance Industry", Applied Financial Economics, 7(1), 37-44.

[34.] Hawawini, G., Subramanian, V., \& Verdin, P. (2003), "Is Performance Driven by Industry or Firm Specific Factors? A New Look at the Evidence”, Strategic Management Journal, 24 (1), 1-16.

[35.] Holzmuller, H. H. and Helmut, K. (1991), "On A Theory Of Export Performance”, Management International Review, 31, 45-70.

[36.] Hovey, M. (2007), "Leverage, Profitability and the Ownership Structure of Listed Firms in China" Available at: http://ssrn.com (13.01.2014).

[37.] Huang, G. and Song, F.M. (2006), "The Determinants of Capital Structure: Evidence From China", China Economic Review, 17, 14-36.

[38.] Jensen, M. (1986), "Agency Costs of Free Cash Flow, Corporate Finance and Takeovers" American Economic Review, 76, 323-329.

[39.] Jensen, M. and Murphy, K. (1990), "Performance Pay and Top - Management Incentives", Journal of Political Economy, 98 (2), 225-264.

[40.] Jónsson, B. (2007), "Does the Size Matter? The Relationship Between Size And Profitability Of Icelandic Firms", Bifröst Journal of Social Sciences, 1, 43-55.

[41.] Karadeniz, E. \& İskenderoğlu, Ö. (2011), “İstanbul Menkul Kıymetler Borsası'nda İşlem Gören Turizm İşletmelerinin Aktif Kârlılığını Etkileyen Değişkenlerin Analizi”, Turizm Araştırmaları Dergisi, 22 (1), 65-75.

[42.] Kebewar, M. and Shah, S.M.N.A.(2012), "The Effect of Debt on Corporate profitability Evidence From French Service Sector", Munich Personal RePEc Archive, http://mpra.ub.unimuenchen.de/43304/1/MPRA_paper_43304.pdf /23.01.2014.

[43.] Lamberg, S. andValming, S. (2009), "Impact of Liquidity Management on Profitability: A Study of the Adaptation of Liquidity Strategies in a Financial Crisis", Umea School of Business, http://faculty.buffalostate.edu/joth/pk2009/Site/program_files/Chamberlain. pdf/(24.01.2014).

[44.] Lee, J. (2009), "Does Size Matter in Firm Performance? Evidence from US Public Firms", International Journal of the Economics of Business, 16 (2), 189-203.

[45.] Majumdar, S.K. (1997), "The Impact of Size and Age on Firm-Level Performance: Some Evidence from India", Review of Industrial Organization, 12 (2), 231-241.

[46.] Majumdar, S.K. and Chhibber P. (1999), "Capital Structure and Performance: Evidence From a Transition Economy on an Aspect of Corporate Governance", Public Choice, 98, 287- 305.

[47.] Marcus, M. (1969), "Profitability and size of firm", Review of Economics and Statistics, February, 104-107.

[48.] Margaritis, D. and Psillaki, M. (2007), "Capital Structure and Firm Efficiency", Journal of Business Finance \& Accounting, 34, 1447-1469.

[49.] Margaritis, D. and Psillaki, M. (2010), "Capital Structure, Equity Ownership and Firm Performance”, Journal of Banking \& Finance , 4, 621- 632. 
[50.] Markman, G. D., Gartner, W.B. (2002). "Is Extraordinary Growth Profitable? A Study of Inc. 500 High-Growth Companies", Entrepreneurship Theory and Practice, 65-75.

[51.] Mesquita, J.M.C. and Lara, J.E. (2003), "Capital Structure and Profitability: The Brazilian Case, Academy of Business and Administration Sciences Conference, Vancouver, July 11-13.

[52.] Miller, M., and Orr, D. (1966), "A Model of the Demand for Money by Firms", Quarterly Journal of Economics, 80, 413-435.

[53.] Moballeghi, M.and Moghaddam, F.G. (2013), "Firm Size, Beta and Financial Leverage: Stock Exchange in Iran", SCMS Journal of Indian Management, April-June, 40-47.

[54.] Nucci, F., Pozzolo, A., \& Schivardi, F. (2005), "Is Firm's Productivity Related to Its Financial Structure? Evidence from microeconomic data", (Working Paper). Italy: Banca d'Italia, Research Department

[55.] Nunesa, P. J. M., Serrasqueiroa, Z. M. and Sequeirab, T. N. (2009), "Profitability in Portuguese Service Industries: a Panel Data Approach”, The Service Industries Journal, 29, (5), 693-707

[56.] Opler, T., Pinkowitz, L., Stulz R., and Williamson, R. (1999), “The Determinants and Implications of Corporate Cash Holdings" Journal of Financial Economics, 52, 3-46.

[57.] Ozgulbas, N., A.S. Koyuncugil and Yilmaz, F. (2006), "Identifying the Effect of Firm Size onFinancial Performance of SMEs", The Business Review, Cambridge, 6 (1), 162-167.

[58.] Padron, Y., Aplinario, G., Santana, O. M., Martel, M.C.V, and Sales, L.J. (2005), "Determinants Factors of Leverage: An Emprical Analysis of Spanish Corporations", Journal of Risk Finance, 6 (1), 60-68.

[59.] Papadogonas, T.A. (2007), "The Financial Performance of Large and Small Firms: Evidence From Greece", Int. J. Financial Services Management, 2, No. 1/2, 14 - 20.

[60.] Pervan, M. and Visic, J. (2012), "Influence of Firm Size on Its Business Success", Croatian Operational Research Review (CRORR), 3, 213-224.

[61.] Pi, L., \& Timme, S. (1993), "Corporate Control and Bank Efficiency", Journal of Banking and Finance, 17(2-3), 515-530.

[62.] Porter, M.E., (1985), "Competitive Advantage: Creating and Sustaining Superior Performance", New York, Free Press.

[63.] Porter, M.E., (1998), “Competitive Strategy: Techniques for Analyzing Industries and Competitors", New York, Free Press.

[64.] Pottier, S. (1998), "Life Insurer Financial Distress, Best's Ratings and Financial Ratios", The Journal of Risk and Insurance, 65 (2), 275-278.

[65.] Rajan, R.G. and Zingales, L. (1995), "What Do We Know About Capital Structure? Some Evidence From International Data", The Journal of Finance, 50 (5), 1421-1460.

[66.] Rao N. V., Al-Yahyaee K. H. M. and Syed L. A. M. (2007), "Capital Structure and Financial Performance: Evidence From Oman", Indian Journal of Economics and Business, 7, 1-14.

[67.] Saliha, T. \& Abdessatar, A. (2011), "The Determinants Of Financial Performance: An Empirical Test Using The Simultaneous Equations Method", Economics and Finance Review, 10 (1), 01 19.

[68.] Scherer, F.M., (1973) “The Determinants of Plant Sizes in Six Nations", Review of Economics and Statistics, May, 135-145.

[69.] Serrasqueiro, Z.S. \& Nunes, P.M. (2008), "Performance And Size: Empirical Evidence From Portuguese SMEs", Small Business Economics, 31 (2), 195 - 217.

[70.] Sexton, D.L., Pricer, R.W., \& Nenide, B. (2000), "Measuring Performance in High Growth Firms", Paper Presented at the Babson Entrepreneurship Research Conference, Wellesley, MA: June.

[71.] Shepherd, W.G., (1972) "The Elements of Market Structure", Review of Economics and Statistics, February, 25-37.

[72.] Schmalensee, R., (1985), “Do markets differ much?”, American Economic Review, 75, 341-51.

[73.] Shubita, M.F., Alsawalhah, J.M., (2012), "The Relationship between Capital Structure and Profitability", International Journal of Business and Social Science, 3, 104- 112.

[74.] Slater, S. and Olson, E. (2002), A Fresh Look at Industry and Market Analysis. Business Horizons, 45 (1), 15-22.

[75.] Simerly, R. and Li, M. (2000), "Environmental Dynamism, Capital Structure and Performance: A Theoretical Integration and an Empirical Test", Strategic Management Journal, 21, 31-49. 
[76.] Smyth, David J., W.J. Boyes \& D.E. Pesau, (1975), "Size, Growth, Profits and Executive Compensation in the Large Corporation, Holmes and Meier, London.

[77.] Stierwald, A. (2009), "Determinants of Firm Profitability - The Effect of Productivity and its Persistence", Melbourne Institute of Applied Economic and Social Research. https://editorialexpress.com/cgibin/conference/download.cgi?db_name=ESAM09 \&paper_id=152 (23.01.2014).

[78.] Titman, S. and Wessels, R. (1988), "The Determinants of Capital Structure Choice", The Journal of Finance, 43, (1) 1-19.

[79.] Vijayakumar, A. and Tamizhselvan, P. (2010), "Corporate Size and Profitability-An Empirical Analysis", College Sadhana - Journal for Bloomers of Research, 3, (1), 44 - 53.

[80.] Weill, L. (2008), "Leverage and Corporate Performance: Does Institutional Environment Matter? “, Small Business Economics, 30, 251-265.

[81.] Winter, R. (1994), "The Dynamics of Competitive Insurance Markets", Journal of Financial Intermediation, 3 (4), 379-415.

[82.] Wiwattanakantang, Y. (1999), "An Emprical Study On The Determinants Of The Capital Structure Of Thai Firms", Pacific-Basin Finance Journal, 7, 371-403.

[83.] Wyn, J. (1998), “The Fourth Wave”, Best's Review, 99 (1), 53-57.

[84.] Zeitun, R. and Tian, G. (2007), "Capital Structure and Corporate Performance Evidence From Jordan”, Australasian Accounting Business \& Finance Journal, 1, 40-53.

[85.] Baltagi, B. H. (2014). Econometric Analysis of Panel Data. Fifty Edition. United Kingdom: John \& Wiley Sons, Ltd.

[86.] Reese, S. and Westerlund, J. (2015). "PANICCA-PANIC on Cross-Section Averages". Department of Economics School of Economics and Management. Working Paper. 2015:3. 